\title{
SOME ACTUAL AND PERSPECTIVE PROBLEMS OF THE ROMANIAN SEASIDE - THE BLACK SEA SEASIDE
}

\author{
Mioara Borza ${ }^{1}$ \\ Daniela-Neonila Mardiros ${ }^{2}$
}

ABSTRACT: In the context of globalization, some countries try to apply in tourism, the international management standards. The aim of this paper is to realise an analysis of the mode in which these desiderata are satisfied, to present the forte and the week points of the management policies applied in Romanian tourism and to propose a series of action levers to improve the quality of services. The applicative part make allowance for the realization of a study on services carried out by a series of commercial societies which develops their activities in the tourism domain and which have an intermediary status between the producers of values and the consumers of it. It will be followed the packages services offered to the consumers, comparative with the one of the economic entities which action in the same sector of activity and which is placed in Romania's neighbourhood.

Keywords: tourism, accommodation, littoral, hospitality, classification.

JEL Classifications: Industrial Organization, Industry Studies: Services, Sports; Gambling; Recreation; Tourism.

\section{Introduction}

The tourism, as economic and social phenomenon, knew spectacular and explosive developments in a second half of the twenty century. The wish to travel and to know new things is knew still the ancient times even it have, at the beginning, as main purpose the war, the conquest of new territories or the commercial trades.

In our days the tourism receive a contain much complex looked from the economic, social and spiritual point of view representing the measures ensemble put in application for the organization and development of certain pleasure travels or in other purposes realised through certain organizations, societies or specialised agencies or on one's own account, on a limited period of time.

It can be adding to that the industries which contribute to the tourism needs satisfaction. The tourism potentially is under the influence of the following factors: natural (generally unchanged) and, respective, economic, demographic, political and psychological one (characterised through an accentuated dynamic but with possibilities to be guided in the desired sense).

The tourism potentially and the serving basis lead to a tourism classification on the following categories: mountain and for ski (travel, climatic tourism, winter sports); maritime (climatic cure, heliotherapy, sea baths, therapy mud) - Black Sea; for hunting; cultural (historical and architectonical monuments, museums); sporting (bounded by the great sporting competitions, Olympics game); festivals bounded; commercial (markets, exhibitions).

\footnotetext{
${ }^{1}$ University „Alexandru Ioan Cuza” of Iaşi, mioara@uaic.ro;

${ }^{2}$ University „Alexandru Ioan Cuza” of Iaşi, mardirosdaniela@yahoo.com;
} 


\section{Some aspects of European tourism potential}

Representing the main traditionally region for tourism, the Occidental Europe takes in, among others, the Mediterranean zone, with the biggest tourist concentration in the world, being, in the same time, the area with the ancient traditions; even the main centres are localised on the coast zone, the Mediterranean basin also cover big urban centres (Rome, Venice, Florence, Granada, Cordoba, Athena); to that it can be add the maritime tourism and the cultural, sportive, hotel, and commercial one so that all the year period is used for all purposes. Yearly, those regions receive over 15 million of tourists.

Greece represents maybe the country with the most ancient traditions in tourism, a special attraction being, around the littoral zone, Athena with the surroundings (Pelopones, the Rodos Islands, Crete, Ionice strained of Greeks history and civilisation's evidences).

The Oriental Europe was opened, as touristic area, only in the ' $90^{\text {th }}$, on a special interest being the Black Sea resorts, on the Romanian and, also, on the Bulgarian littoral (Varna, Burgas, Gold Sands).

Romanian's touristic potential is gave by the natural resources (the relief variety, the climate, fauna and flora) and, also by other resources (archeological vestiges, historical and architectonical monuments, museums, memorial houses), the last one being an important part of the Romanian tourism and being bounded by the Romanian people forming and continuity, by the ancient walled cities on the Euxin Pont littoral and by the Orăştie ruins.

Although the touristic activity on the Romanian littoral is characterised through a powerful seasoning, the littoral tourism is considered the most important form of tourism in Romania because the littoral offers, around the natural resources (beach and the sea's waters) also balneary resources (thermo mineral water, sapropelic mud). On the Romanian Black Sea's littoral $(245 \mathrm{~km})$ are arranged sixteen touristic resorts (Năvodari, Mamaia, Eforie Nord, Eforie Sud, Techirghiol, Costineşti, Neptun, Olimp, Jupiter, Cap Aurora, Venus, Saturn etc).

The tourism is an industry which benefit by extreme optimistic previsions for the future, its importance became bigger and bigger, at the world, regional, national and local level. Another aspect which must be underlined is the one that the commercialised touristic products must be careful realised to not affect the surrounding environment and the good developing of the touristic activities.

In the same time, the developing of certain competitive products leads to the life quality improvement and to the launching of the favoured regions. The launching of the touristic products also have special effects looking the bounded established between hosts and tourists, as participants at the tourism act.

From the studies realised by specialised institutes of research from eleven countries in which Romania has Touristic Promotion Offices (Austria, Germany, Italy, Finland, Hungary, Norway, Sweden, Great Britain, Spain, France and Denmark) results that Romania has considerable natural resources and a big potential for the tourism development. In the same time, Romania is a destination which surprises the most of the visitors because of the modest initially expectations owned to an appropriate promotion.

The tourism operators are confronted with the positive surprising of the tourists arrived in Romania, the security feeling being one of the aspects which surprise positively the most of the tourists.

With all that, the national tourism was confronted with the influence of certain factors which leads to the market decreasing, such as: the decreasing of the population level of living, the deterioration of the touristic unities, the investments missing, the opening to the exterior.

The situation of the Romanian tourism on the Black Sea seaside, for the 2001-2006 period of time, is presented in Table 1.

The tourism organized by travel agencies on the Black Sea's seaside, in the same period is presented in Table 2. 
Tourist accommodation capacity and activity on the Black Sea seaside

\begin{tabular}{|c|c|c|c|c|c|c|}
\hline \multirow{4}{*}{$\begin{array}{l}\text { Indicators } \\
\qquad \begin{array}{l}\text { Structure of tourists reception with functions of tourists } \\
\text { accommodation of which: hotels (number) }\end{array}\end{array}$} & \multicolumn{6}{|c|}{ Period of time (years) } \\
\hline & 2001 & 2002 & 2003 & 2004 & 2005 & 2006 \\
\hline & 767 & 758 & 793 & 844 & 891 & 919 \\
\hline & 258 & 259 & 270 & 275 & 285 & 291 \\
\hline \multirow[t]{2}{*}{ Existing capacity of which: hotels (places) } & 117.428 & 116.419 & 116.531 & 116.935 & 117.218 & 118.778 \\
\hline & 73.691 & 73.589 & 73.265 & 73.665 & 74.222 & 74.624 \\
\hline \multirow{2}{*}{$\begin{array}{l}\text { Capacity in function of which: hotels } \\
\text { (thou-places-days) }\end{array}$} & 9.671 & 10.390 & 10.516 & 10.383 & 9.919 & 9.423 \\
\hline & 7.213 & 7.657 & 7.931 & 7.788 & 7.593 & 7.233 \\
\hline \multirow[t]{2}{*}{ Arrivals of whom: foreigners (thou) } & 659 & 685 & 718 & 755 & 713 & 686 \\
\hline & 45 & 58 & 67 & 84 & 88 & 62 \\
\hline \multirow[t]{2}{*}{ Overnight stays of which: foreigns (thou) } & 4.530 & 4.290 & 4.201 & 4.338 & 4.027 & 3.746 \\
\hline & 373 & 435 & 468 & 593 & 634 & 445 \\
\hline Indices of net using the capacity in function $(\%)$ & 46,8 & 41,3 & 39,9 & 41,8 & 40,6 & 39,8 \\
\hline Average duration of stay (days) & 6,9 & 6,3 & 5,8 & 5,7 & 5,6 & 5,5 \\
\hline
\end{tabular}

Table no. 2

The internal touristic actions organized by travel agencies on the Black Sea's seaside

\begin{tabular}{|l|l|l|l|l|l|l|}
\hline \multirow{2}{*}{ Indicators } & \multicolumn{5}{c|}{ Period of time (years) } \\
\cline { 2 - 8 } & \multicolumn{1}{|c|}{$\mathbf{2 0 0 1}$} & $\mathbf{2 0 0 2}$ & $\mathbf{2 0 0 3}$ & $\mathbf{2 0 0 4}$ & $\mathbf{2 0 0 5}$ & $\mathbf{2 0 0 6}$ \\
\hline Tourists (thou persons) & 376 & 304 & 318 & 389 & 332 & 349 \\
\hline Tourists - days (thou) & 2.992 & 2.436 & 2.410 & 2.841 & 2.441 & 2.490 \\
\hline Average duration of stay (days) & 8,0 & 8,0 & 7,6 & 7,3 & 7,4 & 7,1 \\
\hline
\end{tabular}

Travels of the Romanian people, for holidays in Bulgaria or Greece in the 2004-2006 period of time are presented in table 3.

Table no. 3

Travels of the Romanian people, for holidays in Bulgaria or Greece in the 2004-2006 period of time

\begin{tabular}{|l|l|l|l|}
\hline \multirow{2}{*}{ Countries } & \multicolumn{2}{c|}{ Period of time (years) } \\
\cline { 2 - 4 } & \multicolumn{1}{|c|}{$\mathbf{2 0 0 4}$} & \multicolumn{1}{c|}{$\mathbf{2 0 0 5}$} & \multicolumn{1}{c|}{$\mathbf{2 0 0 6}$} \\
\hline Bulgaria & 2.633 & 3.200 & 16.562 \\
\hline Greece & 34.655 & 56.052 & 64.567 \\
\hline
\end{tabular}

Looking the politic in the touristic domain Romania proposes herself a series of objectives, finalised or in course of finalising, such as: 1. The increasing of the touristic circulation on Romania's territory; 2 . The diversification of the offer and the increasing of the services quality.

1. For the first desideratum realisation we have in view a series of actions such the touristic promotion through: the national program for the creation of the tourism brand; the realisation of printed materials and other materials- booklets, folders, posters, touristic presentation films etc., protocol and promotion objects and, also the making actual again of the official site Romaniatourism); the identification and the acquisition of printed promotion materials, objects of promotion and protocol; co financing of selected printed materials and other materials bounded by the promotion program-the realisation of the promotion, communication and image project ,Littoral 2006. The offer of the smile" (till the end of December 2006 and further on); the co financing of 
certain promotion programs through certain documentation visits of the Romanian journalists on the littoral, in the cultural, balneary tourism domain; the participation at the internal and international tourism markets and to other actions developed in country and outside the country; publicity campaigns on television channels and with the occasion of the participation to diverse actions outside the country; publicity campaigns in the national and foreign written press from countries as: (England, Italy, Germany, Hungary, Israel, Sweden, Belgium, Russian Federation, Spain); foreign publicity campaigns in the main means and transport stations, streets panels etc. (England, Italy, Germany, France, Japan, Republic of Moldavia, Spain, Austria); publicity campaigns in the Romanian media; the organisation and the participation to special events, markets and internal tourism exhibitions; the participation to the international events (over 50)- the most important tourism markets from: England, Italy, France, Germany, Russian Federation, China, Hong Kong, Spain, Austria; the organisation of Romania's presentation and promotion events (road-shows, Romanian evenings, days of Romania, mini festivals of tradition and handicrafts); documentation visits for the foreign journalists and tour-operators (Austria, Belgium, China, Germany, Italy, England, USA, Ukraine, The Republic of Moldavia, Russia etc.); the organisation of conferences, symposiums, international reunions together/under the auspice of the World Tourism Organisation and of other international organisms from the tourism domain.

2. The offer diversification and the increasing of the services quality supposed, as actions, the following one: the development of the touristic products through (the development of the mountain-winter touristic product through the national program "Superski in the Carpathians Mountain"); the completion and the actualisation of the general strategies of the tourism development; the completion and the actualisation of the ecotourism, balneary tourism, religious and cultural tourism and mountain tourism strategies; the Romanian touristic information centre program (the development of the touristic information centre network in the main towns and in the national interest resorts, in the same time with the personnel qualification); the "Blue Flag" program (the yearly implementation program for the new beaches and the national, respective the international inspection for the beaches covered by the program); the increasing of the hotel's services quality program "The Q Sigle" (the correlation of the Q criteria with the actual legislation and the yearly inclusion of new hotels into the program); the yearly realisation of the guide on touristic accommodation structures (hotels, motels, villa, cottages, camping, holiday villages, touristic halting places, pensions, restaurants, tourism agencies etc.); the increasing of the touristic quality services through the authorisation and the control of the activities and personnel from the touristic domain; the development of the research and education in tourism: the national program of the personnel training from/for the hotels industry and tourism (qualification, specialization and perfection courses, seminars, manuals printing, guides etc.); the development of the qualifications specific to the sector; the realisation of an active partnership with the professional, employers and unions associations and with the un governmental organizations, in sense of their participation to the regulations in the tourism domain; the harmonization with the UE countries legislation looking the making actual of the tourism specific regulations according to the UE legislation (the legislation looking the organization and the developing of the touristic activities on the Black Sea's littoral, the authorization and protection measures looking the buildings construction in the Black Sea's coast zone, the approval of the norms and criteria of touristic resorts attestation, the touristic receive structures classification etc.); the harmonization of the tourism indicators according to the UE demands for the purpose of informational system adoption according to the UE demands - The Satellite Account; the establishing of the priorities looking the development of the tourism supporting substructure correlated with the general substructure development.

Representing the most known accommodation traditionally structure, the hotels hold the biggest weight in the accommodation unities ensemble caring out, around the main function of accommodation also a series of connected functions for the purpose of a better satisfaction of the client's demand on all their holiday. The contribution of the hotel unities to the services in the 
touristic sector became from the physiological necessities (rest and strength) felt by a person during the travel or the holiday if we know that more than a half of a holiday time for a tourist is consumed inside the accommodation unity choose for the holiday.

The food services have as purpose to satisfy the vital food necessities, according to a series of preferences. Because of the bound between the food consumption and the person's health condition, the manager of the food unities are directly responding by the customer's demands satisfaction and by their food security, indifferent if the used products are from own sources or from other economic sectors. The commercial food address to the applicants with certain preferences for food and drinks and is assured by restaurants, coffee houses, bars etc., by unities with similarly profile which belongs to the commercial hotels enterprises or to other independent structures of commercial food.

Especially for the hotel, restaurant or other firms involved in hospitality operations, the success in business depends, on big part, by the satisfied guests loyalty more than the attraction, each time, of new categories of consumers for which are necessary important promotionally efforts.

In the market economy, the competitiveness maintenance suppose, permanently, creativity and innovation for the new products and services development which must be more sophisticated, delicate and more individualized. That three desideratum impose for the touristic enterprise's managers the periodical re evaluation of the market segments dimensions on which they action and the careful analysis of the products and services in the purpose to eliminate from the offers the products and services with accentuated decreasing profitableness.

Beginning with 2008, the classification of the touristic receiving structures have, as priority purpose, the tourists protection looking, first of all, the rooms minimum surface and, also, the eventually existing facilities which permit the granting of a stars number, as the swimming pool, conference room or sports room. Indifferent by the classification exist a series of common rules for all the categories of hotels such as:

- in all receive spaces and in the bathrooms (with the exterior one exception) must be assure, in the cold season, a temperature of minimum $18 \mathrm{C}$ degree and in the warm season of maximum $25 \mathrm{C}$ degree;

- the bathrooms must have permanently warm and cold water, even at one star category;

- the constructions must be realised on a manner to avoid the tourists disturbance because of the noises produced by the building's technical equipments or by other pollution factors;

- are not admitted the underground receive spaces if they have not directly sources of light and ventilation;

- the soft inventory (bedclothes, towels and bath gowns) must be white;

- the obligatory central warming for all types of receiving structures;

- guard own parking (to the 4 stars unities, the apartments hotels and motels; the unities of 2 and 3 stars must have in use auto parking for $20 \%$ from the rooms number; the percentage is of $40 \%$ at the 4 stars unities and of $50 \%$ at the 5 stars one; the one star hotels are not obliged to have parking place);

- the existence of the security and guard service (is not compulsory at one or two stars; is compulsory at three stars with over 50 rooms at to the 4 and 5 stars);

- the air conditioned and the climacteric systems are not compulsory to the hotels, apartments and motels of 1-3 stars inclusive;

- the single room dimension, the proportion of $75 \%$ employees which must new a foreign language, the furniture dimension, the texture of the materials used for curtains, draperies or bedclothes are other criteria of hotels structures classification;

- at the 4 and 5 stars category, the bedclothes and the towels must be changed in two days and the bath gowns in three days.

The hotel classification category is conditioned by the total carrying out of the compulsory criteria and by the realization of a minimum score resulted from the evaluation of the 
supplementary criteria. In this way, for 5 stars is necessary a score of minimum 150 points, for 4 stars minimum 120 points, 70 points for 3 stars and 30 points for 2 stars. The existence of a bar inside the hotel bring 15 points, 10 points are for the existence of the garages for minimum $20 \%$ of rooms, 10 points for guard own parking (for minimum $30 \%$ of rooms), 30 points for a covered swimming pool, 10 points for beauty saloon or for cleaning services, 2 points for free newspaper and magazines inside the receiving unity, 5 points for the rest green space, indifferent of its dimension, for the existence of a tennis playground or for a room with computers and internet access etc.

With all that demands, in 2008 the number of authorized hotels was 981 with a total of 71.643 rooms. In the same period of time, only $15 \%$ of the total authorized unities were of superior category with all the increasing demand for that.

In the following one we will present the package of touristic services offered by a series of touristic operators which belong to the category of commercial societies of public food organized as hotels and restaurants and which develop their activity in Romania, on the Black Sea littoral, in the Neptun, Mamaia and Costineşti resorts).

The Neptun Resort - looking the accommodation offers that one is presented in Table 4.

Table no. 4

\section{Accommodation offers at hotels and pensions in Neptun Resort}

\begin{tabular}{|l|l|}
\hline $\mathbf{4}$ stars Hotels & Cocor, Meditarraneo, Insula \\
\hline $\mathbf{3}$ stars Hotels & Doina, Sulina, Majestic, Ciresica \\
\hline $\mathbf{2}$ stars Hotels & $\begin{array}{l}\text { Balea, Dobrogea, Terra, Banat, Craiova, Neptun, Romanţa, Caraiman, Dacia, Ovidiu, Slatina, } \\
\text { Clabucet, Delta, Panoramic Amfiteatru, Belvedere, Mioriţa, Istria }\end{array}$ \\
\hline $\mathbf{1}$ star Hotels & Prahova \\
\hline Pensions and villa & La Jura \\
\hline
\end{tabular}

For the realised study, we will present, with details, the situation of the following accommodation structures from that resort: Insula Hotel and Majestic Olimp Hotel. In that way we have in view a short presentation of the respective structure, the services offered by it and the prices in force for the 2009 summer season.

a. The Insula Hotel is placed on the Neptun's lakeside and present a special architecture;

- as general endowments, the hotel dispose of: very spacious rooms, with balcony, air conditioned, fridge, television, internet, telephone; a restaurant (with fish specific, fresh preparations from sweet water fish, from salt water fish or exotic fish and sea fruits), a terrace surrounded by luxuriant vegetation, pontoon on the lake where the tourists can eat, wine cellar and bar; for recreation, near the hotel it can rented boats for sails on the lake; room-service;

- facilities for children: children under 7 years old benefits of free accommodation and the one over that age will pay $50 \%$ from one place's value.

b. placed in the central zone of the resort, the Majestic Hotel is placed perpendicular on the cost fact that mean that all rooms have view to the sea, with the exception of the one from the downstairs; completely restored in 2002, dispose of 455 accommodation places in 205 double rooms and 14 apartments gifted with own bathroom, television, TV cable, fridge, air conditioned, international telephone;

- as general endowments, the hotel dispose of: restaurant, bars, terraces, park, garden (involves more restaurants with international and Romanian specific), outside swimming pool, beauty saloon, fitness room, sauna, children playground, exchange office, parking;

- facilities for children: two adults and a child of 0-6 years receives free accommodation and breakfast for the child (without supplementary bed); two adults and a child of 6-12 years receives free accommodation for the child (without supplementary bed) but pays $50 \%$ from the breakfast 
price for the child (10 lei); an adult and a child accommodated in double room in regime of single room, for the child will be paid the lunch services according to the age.

Accommodation prices some of the Neptun's resort hotels are presented in Table 5.

Table no. 5

Accommodation prices in Neptun 2009

\begin{tabular}{|c|c|c|c|c|c|c|}
\hline \multicolumn{7}{|c|}{ Insula Hotel $\left(4^{* * * *}\right)-$ lei } \\
\hline \multicolumn{2}{|l|}{ Period of time } & 01.06-18.06 & 19.06-30.06 & 01.07-13.07 & 14.07-24.07 & 25.07-18.08 \\
\hline \multicolumn{2}{|c|}{ double room and breakfast } & 189 & 239 & 315 & 376 & 440 \\
\hline \multicolumn{2}{|c|}{ double room and half pension } & 251 & 301 & 376 & 440 & 502 \\
\hline \multicolumn{2}{|c|}{ double room and full pension } & 315 & 365 & 440 & 502 & 565 \\
\hline \multicolumn{2}{|l|}{ Period of time } & 18.08-24.08 & 25.08-30.08 & 31.08-11.09 & 12.09-17.09 & 18.09-30.09 \\
\hline \multicolumn{2}{|c|}{ double room and breakfast } & 376 & 315 & 239 & 189 & 164 \\
\hline \multicolumn{2}{|c|}{ double room and half pension } & 440 & 376 & 301 & 251 & 226 \\
\hline \multicolumn{2}{|c|}{ double room and full pension } & 502 & 440 & 365 & 315 & 290 \\
\hline \multicolumn{7}{|c|}{ Majestic Hotel $\left(3^{* * *}\right)-$ lei } \\
\hline Period of time & 20.05-31.05 & 01.06-18.06 & 27.08-10.09 & 19.06-09.07 & \multicolumn{2}{|l|}{$10.07-26.08$} \\
\hline double room & 138 & 161 & 161 & 196 & \multicolumn{2}{|c|}{$\begin{array}{l}403 \text { (includes also food tickets in } \\
\text { value of } 130 \text { lei/day) }\end{array}$} \\
\hline single room & 115 & 138 & 138 & 173 & \multicolumn{2}{|c|}{$\begin{array}{l}305 \text { (includes also food tickets in } \\
\text { value of } 65 \text { lei/day) }\end{array}$} \\
\hline
\end{tabular}

The Mamaia Resort - looking the accommodation offers, these are presented in Table 6.

Table no. 6

\section{Accommodation offers at hotels in Mamaia Resort}

\begin{tabular}{|l|l|}
$\mathbf{5}$ stars Hotels & Vega, Palm Beach, Mamaia \\
\hline $\mathbf{4}$ stars Hotels & $\begin{array}{l}\text { Malibu, Iaki, Savoy, Florida, Laguna, Gociman, Spendid, Amiral, Comandor, Golden Tulip, } \\
\text { Modern, Condor, Richmond, Palas }\end{array}$ \\
\hline $\mathbf{3}$ stars Hotels & $\begin{array}{l}\text { Regal, Oxford, Majestic, Perla, Central, Victory, Ambasador, Dorna, Orfeu, Riviera, Albatros, } \\
\text { Astoria, Pelican } \\
\text { National, Patria, Unirea, Aurora, Selena, Victoria, Piccadilly, Doina, Alcor, Flora, Fati Club }\end{array}$ \\
\hline
\end{tabular}

For the realized study, we will present, with details, the situation of the following accommodation structures from that resort: Vega Hotel, Malibu Hotel and Victory Hotel. In that way we have in view a short presentation of the respective structure, the services offered by it and the prices in force for the 2009 summer season.

a. placed in the north side of the Mamaia resort, on the sea's coast and having directly exit to the beach the Vega Hotel is reopened in the summer of 2008, completely renovated and modernized, with an elegant interior and which involved a series of exotic elements; have 125 receiving spaces dispose on eight floors and organized in the following way: 36 double rooms with a matrimonial bed, 27 double rooms with two separated beds, 7 superior double (one for persons with disabilities), 17 family room, 15 Senior Suite, all with sea view, individual acclimatization installation, internet, mini bar, safe, LCD, bathroom with shower etc; 
- as general endowments, the hotel dispose of: restaurant, spa centre, bar with terrace, conference room, swimming pool and basin with warm water for adults and children, private beach with three beach-bars, playground for children, football and volleyball field, recreation boats, guarded parking; for recreation the hotel offer the possibility to rent ski-jets and hydro bicycles.

b. the Malibu Hotel is built even at the entrance of the Mamaia resort being a new hotel, opened in the 2006 summer and which offer to the tourist modern interiors, with quality finishing, elegant and comfortable decorated, in warm and resting colours; is an imposing construction, placed directly on the beach and its location between the lake and sea offer to the guests the original possibility to admire the sunrise from the sea and the sunset in the water of the lake; straight to the hotel the beach is wide and the sea's water is very calm; the hotel have 156 double rooms and 22 apartments, all with mini bar, international telephonic line, TV cable, conditioned air, balcony;

- as general endowments, the hotel dispose of: reception room with 300 places, conference centre (with four rooms with a capacity between 80-350 places), restaurant (180 places), lobby-bar, spa centre with Jacuzzi, wet and dry sauna, fitness room, massage room, parking place;

- facilities for children: children under two benefits by free accommodation; between 2-6 years old free accommodation with paid breakfast in value of 30 lei/day; over 6 years old for children must be paid 90 lei/day with breakfast included.

Accommodation prices some of the Neptun's resort hotels are presented in Table 7.

Table no. 7

Accommodation prices in Mamaia 2009

\begin{tabular}{|c|c|c|c|c|c|c|}
\hline \multicolumn{7}{|c|}{ Vega Hotel $\left(5^{* * * * *}\right)-$ lei } \\
\hline Period of time & 05.01-28.02 & \multicolumn{2}{|c|}{ 01.03-30.04 } & \multicolumn{2}{|l|}{ 01.05-30.06 } & 01.07-30.08 \\
\hline double room & \multicolumn{2}{|l|}{295} & 390 & \multicolumn{2}{|l|}{$542 / 692$} & $980 / 1130$ \\
\hline $\begin{array}{l}\text { superior double } \\
\text { room }\end{array}$ & 395 & \multicolumn{2}{|l|}{490} & \multicolumn{2}{|l|}{$642 / 792$} & $1080 / 1230$ \\
\hline family room & 475 & \multicolumn{2}{|l|}{630} & $870 / 1110$ & & $1580 / 1730$ \\
\hline Junior suite & 495 & \multicolumn{2}{|l|}{590} & \multicolumn{2}{|l|}{$790 / 990$} & $1230 / 1380$ \\
\hline Senior suite & 595 & \multicolumn{2}{|l|}{690} & $890 / 1140$ & \multicolumn{2}{|c|}{$1380 / 1680$} \\
\hline \multicolumn{7}{|c|}{ Malibu Hotel $\left(4^{* * * * *}\right)$ - lei } \\
\hline \multicolumn{7}{|c|}{ touristic series with breakfast included } \\
\hline Period of time & 08.06-15.06 & 15.06-22.06 & 22.06-29.06 & 29.06-06.07 & 06.07-13.07 & $13.07-24.08$ \\
\hline \multirow[t]{3}{*}{ double room } & 1682 & 1812 & 1966 & 2170 & 2276 & 2437 \\
\hline & 24.08-31.08 & 31.08-07.09 & 07.09-14.09 & & & \\
\hline & 2089 & 1966 & 1640 & & & \\
\hline \multicolumn{7}{|c|}{\begin{tabular}{|l|} 
outside the touristic series $\mathrm{room} / \mathrm{day}$ \\
\end{tabular}} \\
\hline Period of time & 01.01-11.06 & 12.06-25.06 & 25.06-09.07 & $10.07-22.08$ & 23.08-05.09 & $06.09-31.12$ \\
\hline single room & 179 & 259 & 287 & 345 & 259 & 191 \\
\hline double room & 224 & 293 & 334 & 392 & 316 & 235 \\
\hline standard apartment & 370 & 489 & 509 & 544 & 489 & 381 \\
\hline jacuzzi apartment & 415 & 546 & 567 & 603 & 546 & 426 \\
\hline
\end{tabular}

Costineşti Resort is placed in the prolongation of the village with the same name, at $31 \mathrm{~km}$ at south of Constanţa and is neighbouring at north with the Tuzla village $(7 \mathrm{~km})$ and to the south with the Olimp resort $(5 \mathrm{~km})$. Is a resort for young people being characterized through a hospitable and cheerful atmosphere. Looking the accommodation that are the one presented in Table 8. 
Table no. 8

Accommodation offers at hotels and pensions in Costineşti resort

\begin{tabular}{|l|l|}
\hline $\mathbf{4}$ stars Hotels & Stefania \\
\hline $\mathbf{3}$ stars Hotels & Iunona, Pierre, Stefania \\
\hline 2 stars Hotels & Forum, Meridian, White Inn, Regal, Alex, Amiral, Costineşti, Cris, Scoica \\
\hline Pensions and villa & $\begin{array}{l}\text { Bibi, Alfa Beta Gama, Delta, Costel şi Mirela, Florentina, Marinn, Paun, Roby, Sofia, Vicki, } \\
\text { Victoria, Micul Paris, Complex Corsa, Bel Air, Casa Dalena, Iris }\end{array}$ \\
\hline
\end{tabular}

For the realized study, we will present, with details, the situation of the following accommodation structures from that resort: Stefania Hotel, Regal Hotel and Scoica Hotel. In that way we have in view a short presentation of the respective structure, the services offered by it and the prices in force for the 2009 summer season.

a. placed in the resort's centre, the Stefania Hotel is at $200 \mathrm{~m}$ from the beach and, respective at $100 \mathrm{~m}$ for the train station; have 200 accommodation places disposed in 55 rooms completely restored with three stars endowments (bathroom, television, fridge, telephone) and respective 40 double rooms, new built, with four stars endowments (bathroom, air conditioned, television, fridge, telephone in room and bathroom, internet) and three apartments;

- as general endowments, the hotel dispose of: restaurant (with 200 places capacity), three conference rooms, each with 50 places, terrace (where the tourists can eat) and own parking;

- facilities for children: children between 0-10 years old have free accommodation without supplementary bed and for the second child will be paid $50 \%$ from one's place with supplementary bed value; the children between 10-12 years old pays 50\% from one's place value; children over 12 years old will pay all the services, entirely.

b. the Scoica Hotel is a new one, opened in 2007 and benefits by a very good position being built at only $30 \mathrm{~m}$ of beach; it have 44 rooms, each with a series of endowments (bath with shower, air conditioned, television set, cable TV, fridge, new furniture); as general endowments, the hotel dispose of: a restaurant, terrace, inside garden, day-bar and parking place.

c. placed at $50 \mathrm{~m}$ from the sea, near the summer theatre, the Regal Hotel is open all the year, is a new hotel and offers to the tourists quality services and endowments (48 double rooms and 4 flats modern and comfortable arranged, each with own bath with shower and bath, mini bar, television set, air conditioned);

- as general endowments, the hotel dispose of: a restaurant, a beautiful internal garden, terrace and conference room (with 100 places, $40 \mathrm{PC}$ and internet);

- facilities for children: children between 0-12 years old have free accommodation and the second child benefits of $50 \%$ reduction from a place value; the supplementary bed represents $50 \%$ from one place's value.

Accommodation prices some of the Neptun's resort hotels are presented in Table 9.

Table no. 9

Accommodation prices in Costineşti 2009

\begin{tabular}{|c|c|c|c|c|c|}
\hline \multicolumn{6}{|c|}{ Stefania Hotel $\left(3^{* * *}\right.$ and $\left.4^{* * * *}\right)$ - lei } \\
\hline Period of time & 01.06-14.06 & $15.06-28.06$ & 29.06-19.07 & $20.07-23.08$ & 24.08-13.09 \\
\hline double room $3^{* * *}$ & 170 & 198 & 221 & 277 & 209 \\
\hline double room $4^{* * *}$ & 226 & 266 & 305 & 384 & 288 \\
\hline food price & \multicolumn{5}{|c|}{ lunch or dinner - 35 lei/person/day - value tickets } \\
\hline \multicolumn{6}{|c|}{ Scoica Hotel $\left(2^{* * *}\right)-$ lei } \\
\hline Period of time & 01.06-30.06 & \begin{tabular}{|l|}
$01.07-14.07$ \\
\end{tabular} & $15.07-20.08$ & 21.08-31.08 & \begin{tabular}{|l|}
$01.09-30.09$ \\
\end{tabular} \\
\hline
\end{tabular}




\begin{tabular}{|c|c|c|c|c|c|c|c|}
\hline \multicolumn{2}{|l|}{ double room } & 127 & 161 & 253 & \multicolumn{2}{|l|}{161} & 127 \\
\hline \multicolumn{2}{|l|}{ food price } & \multicolumn{6}{|c|}{$\begin{array}{l}\text { are gives in the own restaurant - breakfast }- \text { Sweden buffet; for the other food, the } \\
\text { restaurant menu cover preparations belongs to the international kitchen }\end{array}$} \\
\hline \multicolumn{8}{|c|}{ Regal Hotel $\left(2^{* *}\right)$ - lei } \\
\hline Period of time & 01.01-25.04 & 26.04-15.06 & $16.06-30.06$ & 01.07-15.07 & 16.07-20.08 & 21.08-31.08 & 01.09-15.09 \\
\hline double room & 130 & 144 & 175 & 187 & 240 & 187 & 144 \\
\hline flat & 160 & 187 & 226 & 264 & 288 & 264 & 187 \\
\hline
\end{tabular}

Proposals for the improvement of tourist activities in Romania

1. What is necessary for Romania are not indispensable the new inventions from the tourism domain but an adequate marketing and an attention straight to the fact that that country have more opportunities to give for the one interested to try something different.

2. Looking the touristic products, chapter in which Romania, we sadly must say, has more to learn yet, their realization on a superior quality and on the basis of solid researches bounded by the customers demands, can influence the development of the respective zone through: the attracting of a bigger and bigger number of foreign tourists in the area; the modernization and the extension of the transport, food, accommodation substructures to not affect the existing surrounding environment; new jobs and the human resources development through the employees improvement, the keeping of the traditions continuity, of the customs and, also, of the spiritual values.

3. The customer is sovereign and, as result, he is not an ,unthinking pawn” manipulated to buy everything the trader offers to him. As a rule, the customer behaviour is decided and orientated to a purpose, the products and services being accepted according to the induced satisfaction reported to the needs and to the own life style.

4. Never after a research can't make a perfect prediction of the customer behaviour looking the products and services offered by the tourism operators. With all that, a correct projection and good oriented research effort can reveal significant marketing error and can orientate the tourism activity in the future.

The implementation of these ideas, thereupon we can add other issues for improvement and development of Romanian tourism, is a real chance to increase the number of Romanian and foreign tourists, and the registration of the Romanian tourism in the category of the European one.

\section{References:}

1. Commission of the European Communities, 2003. Basic orientations for the sustainability of European tourism. Communication from the Commission, Brussels;

2. Commission of the European Communities, 2006. A renewed EU Tourism Policy: Towards a stronger partnership for European Tourism. Communication from the Commission, Brussels;

3. Holden, A., 2000. Environment and Tourism, Routledge, London;

4. Iarca (Stănescu), D.M., 2007. Research on estimating the quality and efficiency in tourism services, PhD Thesis, Academy of Economic Studies, Bucureşti;

5. Ispas, A., 2007. Romania's image as tourist destination. Review "Economic talks", no. 4/April 2007, pp.48-53;

6. Stănciulescu, G.., 2004. The management of sustainable tourism in the urban centers, Economics Publishing House, Bucureşti;

7. Verheugen, G., 2005, A renewed EU Tourism Policy: Towards a stronger Partnership for European Tourism, speech, Malta;

8. $<$ http://www.financiarul.com> and http://www.tmctv.ro/articol_5231, Fewer tourists in 2006 on the Romanian seaside, Money Channel, 12.01.2006, viewed at 25 March, 2009: 
9. http://www.insse.ro/cms/files/pdf/ro/cap20.pdf, Romanian Statistical Yearbook, Chapter 20 Tourism, viewed at 10 March 2009

10. $<\mathrm{http}: / /$ www.world-tourism.org/facts/eng/vision.htm>, Tourism 2020 Vision, viewed at 2 April 2000 